\title{
Does the IMF Influence Fiscal and Monetary Policy?
}

\author{
Axel Dreher* \\ Journal of Policy Reform, forthcoming 2005
}

\begin{abstract}
In theory, the IMF could influence fiscal and monetary policy via several channels, among them advice to policy makers, conditionality, and moral hazard it induces with the borrowers. This paper tries to disentangle those effects empirically. Using panel data for 98 countries over the period 1975-2000 it analyzes whether IMF involvement indeed influences fiscal and monetary policy in program countries. There is evidence that participation in IMF Standbyand Extended Fund Facility arrangements improves economic policy. Money disbursed and the degree to which a program is implemented does not have any systematic influence. The same is true for future availability of resources as measured by exhaustion of a country's quota with the Fund. The final section discusses policy implications.
\end{abstract}

Keywords: IMF programs, fiscal policy, monetary policy, compliance, conditionality, moral hazard

JEL-Codes: F33, F34, O57 


\section{INTRODUCTION}

The International Monetary Fund has come under increased scrutiny and attack, with some of the most intense criticisms aiming at the ineffectiveness of its programs and conditionality (e.g. Przeworski and Vreeland 2000, Dreher and Vaubel 2004a). The channels by which the IMF could influence economic policies and outcomes, however, have rarely been made explicit.

In principle, the Fund can influence economic policies and outcomes by its available or disbursed money, the policy conditions it attaches to its loans and, more generally, its policy advice. ${ }^{1}$ The overall effect of the IMF depends on the net effect of those channels. Nevertheless, the literature so far made no attempt to disentangle them, the exception being Dreher (2004a), who studied the influence of the IMF on economic growth in the borrowing countries.

In this paper, I analyze the effects of programs, disbursed loans, loans potentially available in the future, and compliance with conditionality on fiscal and monetary policy. With respect to compliance, three different proxies are employed to test whether implementation of IMF conditionality influences those policies. The paper thus combines the literature on the IMF’s influence on economic policy with those on compliance.

What I find is, basically, that when endogeneity of IMF programs is adequately controlled for, there is some evidence that Standby- and Extended Fund Facility Arrangements reduce budged deficits and money growth. This result, however, is independent of the degree to which a program is implemented, as measured by irreversible program interruptions, the share of money agreed upon that is actually disbursed, or, respectively, a measure based on the share of conditions that is complied with. IMF loans available and disbursed do not have any effect on economic policy.

The next section shortly summarizes what we know about the implementation of IMF conditions. Section 3 discusses the various channels by which the IMF could influence 
economic policy; section 4 describes method and data employed and section 5 presents the empirical analysis. The final section discusses policy implications and concludes.

\section{IMPLEMENTATION OF IMF CONDITIONALITY}

Measuring the implementation of IMF conditions is not straightforward. Many earlier studies employed proprietary data, mostly from the Fund's internal documents. These studies show that compliance with conditionality is usually in the range between 40-60 percent (Beveridge and Kelly 1980, Haggard 1985, Edwards 1989).

More recently, Edwards (2001) analyzed 347 programs between 1979 and 1997. He gathered information from different sources, including the Fund's archives, on whether a program was suspended. Over the whole period of study, 138 programs have been suspended prior to expiration, corresponding to a completion rate of 60 percent.

Since the beginning of the Nineties the IMF itself provides data on compliance with conditionality. Its database on Monitoring Fund Arrangements (MONA) contains data on the implementation of performance criteria and structural benchmarks that have been implemented under its programs. In the MONA database, compliance is scored as a 0-1 indicator per criterion. At each review an average for a given program is generated. When a condition is not met and a waiver is granted, the record is still "non-compliance" or 0.

Mercer-Blackman and Unigovskaya (2004) use MONA data to give evidence on compliance in countries in transition to market economies. Of the 33 countries analyzed, only 17 implemented more than 50 percent of the structural benchmarks included under their program over the period 1993-97. The IMF (2001) itself reports compliance with structural benchmarks in 57 percent of all programs in 1987-99. Compliance with performance criteria was almost ten percentage points higher, while prior actions have been implemented in 80 percent of the programs analyzed. 
The most widely used measure of program implementation has been a proxy suggested by Killick (1995). He employed IMF loans agreed but left undrawn at program expiration as an indicator of performance under a program. When 20 percent of the agreed money remaining undrawn at program expiration is taken as cut-off, 47 percent of IMF programs are completed. Killick finds that over the period 1979-93 compliance was higher in earlier programs; and also in Standby as compared to Extended Fund Facility (EFF) arrangements.

Bird and Willett (2004) summarize the disadvantages of this approach. Resources may not be withdrawn, because of improvements in the economy. Sometimes programs are approved on a precautionary basis only, without intension to draw at all. On the other hand, the Fund might disburse its money even though implementation of conditions has been low, for example because it feels that significant progress has been made, or even for political reasons. Also, not all programs cancelled and renegotiated soon after represent signs of failure. There is an additional shortcoming with this approach to measuring compliance (Dreher 2003). If countries fail to implement conditions at the beginning of a multi-year arrangement, money will be withheld. In many cases this money will be paid out later, after agreement about future conditions is reached. Though non-compliance might be severe during major parts of the program period, finally the whole amount is disbursed, what would not be reflected by Killick's indicator. The exact amount of non-compliance is thus difficult to assess and, clearly, this variable allows different interpretations.

\section{CHANNELS FOR THE IMPACT OF THE IMF ON ECONOMIC POLICY}

There is a multitude of channels by which the IMF can influence economic policy. First, program approval is obviously associated with a certain amount of money. The effect of this money is, however, not evident. While, in theory, IMF credit is meant to alleviate restructuring the economy, in practice the result might be the exact opposite: Money disbursed increases borrowing governments' leeway, thus reducing incentives to reform 
(Boockmann and Dreher 2003). As a consequence, governments might pursue inappropriate policies longer than they otherwise would.

Second, availability of IMF money may deteriorate economic policy even before it has been disbursed. According to the "moral-hazard hypothesis", IMF lending may be interpreted as a (subsidized) income insurance against adverse shocks (Vaubel 1983). The insurance cover induces the potential recipients to excessively lower their precautions against such damages (or even to intentionally generate a crisis). There is a considerable body of evidence that the balance of payments problems of IMF borrowers have been largely of their own making and that macroeconomic performance during inter-program years has been deteriorating as the number of past programs increased (Evrensel 2002). Participation in IMF programs thus increases the probability of future programs (Conway 1994). As has been shown by Dreher and Vaubel (2004a), economic policy is indeed more expansive in countries with higher IMF loans available (as measured by the country's undrawn resources with the Fund).

The Fund, third, attaches policy conditions to its loans. Those conditions usually aim directly at improving fiscal and monetary policy (usually by including conditions on credit growth). Implementation of those conditions should thus reduce monetary expansion and the budget deficit directly. There are also indirect effects: Many conditions included under IMF programs aim at structural and institutional reforms. Those reforms are designed to make future crises less likely and could contribute to achieving more conservative fiscal and monetary policies. However, it has been shown that non-compliance and program interruptions are quite frequent (see section 2). If conditions are not implemented, of course, they cannot have any impact on economic policy.

A fourth channel by which the IMF can influence policy is its advice (Boockmann and Dreher 2003). Advice of the IMF is often discussed publicly and may influence politics in the longer run (Killick 1994: 156). According to Fischer (2001: 237), one of the IMF's main 
contributions to reforms is that it stands consistently for a particular approach to economic policy. Therefore, the impact of the IMF may reach beyond the immediate effects of conditions and finance. IMF advice to policymakers might thus improve policy independent of direct conditionality.

\section{METHOD AND DATA}

The regression is a pooled time-series cross-section analysis. The data cover the time period 1975-2000 and extend to a maximum of 96 countries. Since some of the data are not available for all countries or years, the panel analysis is unbalanced and the number of observations depends on the choice of explanatory variables.

The dependent variables are the overall budget deficit in percent of GDP and the rate of monetary expansion (money and quasi money). As possible covariates, a huge number of economic and political variables has been suggested in the literature. From sources commonly used in cross-country time-series estimation, I could obtain data for more than 30 of those variables. In choosing the variables finally included in the regressions, I followed a general to specific approach, dropping all variables, which did not have a coefficient significant at the ten percent level. As it turned out, the significant variables are the same in the fiscal and monetary regressions. The selection procedure leads to the choice of the following control variables:

- Real GDP growth (in percent),

- the number of years remaining from the current governments' term in office,

- a dummy for flexible exchange rate regimes and

- $\quad$ the lagged endogenous variable.

A dummy for each country is included in all regressions; dummies for each year are included in the deficit regressions but have been found to be insignificant in the money growth regressions. 
As has been argued in section 3, the IMF might influence policy via its advice, conditionality, money, and moral hazard it induces with the borrowing governments. Only one of those channels can be directly measured: IMF loans disbursed (in percent of GDP). To proxy the degree of implementation of conditionality, ${ }^{2}$ three different variables (introduced in section 2) are employed. First, I use the share of the agreed money actually disbursed. Second, I employ the dummy for suspension of IMF programs constructed by Edwards (2001). The third measure is the dummy for major interruptions during the program period (Nsouli, Mourmouras and Atoian 2003), which is available for the period 1992-2000 only. For the empirical analysis, the three interruption measures are recoded in a way that they represent compliance instead of non-compliance. However, the different proxies do not provide a consistent picture of compliant behavior. The results of the empirical analysis thus have to be interpreted cautiously.

In principle, the amount of IMF credit a country receives may also proxy the direct effect of advice on policies. However, advice and credit volumes are probably not proportional. The number of arrangements in effect might thus be a better measure for advice than the flows of finances (Boockmann and Dreher 2003). Controlling for the amount of credit and compliance with conditionality, the dummy for existing IMF programs would capture the effect of advice. The analysis should cover only those arrangements that were in effect over much of the year in question. Only those years are thus coded as program years, where an IMF program has been active over at least five months.

To test whether the IMF induces moral hazard with its borrowers I use the same variables as Dreher and Vaubel (2004a). The quantity dimension of moral hazard generated by the IMF is measured by the exhaustion of a country's quota with the Fund: as the country's quota is increasingly exhausted and, by implication, the quantity of additional credit available from the IMF diminishes, the incentive to run excessive policies declines. Conversely, moral hazard increases if the country repays its credit to the IMF or if IMF quotas are raised. 
The term "moral hazard" is sometimes also used in a wider sense describing an incentive to abuse the claim to an indemnity once the accident has occurred or an incentive to abuse a loan once it has been disbursed. Net new credit by the IMF captures this effect.

When estimating the regressions by OLS, however, there might be a problem with endogeneity of the IMF variables. Obviously, IMF programs are frequently concluded in times of economic crises. The effect reported for the program variable might thus not reflect the consequences of the program itself but those of the underlying crisis. In other words, there might be a selection problem. ${ }^{3}$ The same is true for the amount of money disbursed, which probably rises with the severity of the crisis.

To account for this, I use instruments for IMF programs and (net) credits disbursed. Obviously, the problem with this is finding reliable instruments. As possible determinants of programs and loans, the initial regressions included a huge number of variables that have been suggested in the literature: the rate of monetary expansion, the overall budget deficit, general government consumption, real GDP growth, GDP per capita, the share of foreign short-term debt in total foreign debt, the total level of outstanding debt, total debt service, the rate of inflation, a country's international reserves, the current account balance, openness to trade (all World Bank 2003) and the LIBOR on three months credits to US banks (IMF 2003). I include the following political and social variables: the degree of democracy (Marshall and Jaggers 2000), fractionalization of the legislature, proportional representation, a dummy for special interest governments, government ideological cohesion, the duration of the political regime and a measure of political instability (all from Beck et al. 2001). Since the dependent variable in the program regression is binary, estimation is by (random effects) probit. The loan regression is estimated by OLS, with a dummy for each individual country included.

From the initial regressions I followed again a general to specific approach, consecutively eliminating the variables with the lowest t-value. Eventually, only determinants 
significant at least at the ten percent level are employed to instrument the IMF variables in the policy regressions.

To account for the endogeneity of the IMF-variables, I estimate 3SLS regressions. In the first stage, 3SLS uses instruments for all endogenous variables. These instruments are the predicted values resulting from a regression of each endogenous variable on all exogenous variables included in the system. The second stage consistently estimates the covariance matrix of the equation errors using the residuals from the 2SLS estimation of each equation. In the third stage, GLS estimation employing the covariance matrix estimated in the second stage and the instruments in place of the endogenous variables is performed.

The next section reports the empirical results. After shortly summarizing the results for the determinants of IMF loans and programs, results for the IMF's impact on economic policy are presented.

\section{EMPIRICAL ESTIMATES}

Table 1 reports results for the determinants of IMF loans and programs. As can be seen, few variables have been found to be significant predictors. Programs are significantly more likely to be in effect the higher government consumption, the lower monetary expansion and the less fractionalized the country's government. New (net) IMF loans rise significantly with low GDP growth. They are lower if the exchange rate of the borrowing country flows freely and if its government represents a special interest group. The lagged endogenous variable is significant at the one percent level. In both regressions, the explanatory variables are jointly significant at the one percent level.

Tables 2 and 3 present results when IMF programs and loans are instrumented with the variables introduced above. ${ }^{4}$ In addition to IMF programs and loans under all facilities, the tables report disaggregated results for the IMF's non-concessional and, respectively, concessional lending facilities. Table 2 reports the results for the overall budget deficit, Table 
3 those for monetary growth. Loans, programs, and quota exhaustion are included individually in the regressions; in addition, the IMF program variable is multiplied with the three different measures of compliance one at a time: the share of agreed loans actually disbursed (columns a), the dummy for no major program interruption during the program period (columns b) and, respectively, Edwards’ measure for program continuation (columns c).

As can be seen, results for the variables not related to the IMF are consistent across the different specifications, with most of the coefficients being significant at the ten percent level at least. The results are easy to explain: Budget deficits and monetary expansion rise with lower economic growth, because of counter cyclical policies. The number of years left in the current term controls for the political business cycle. As can be seen, fiscal and monetary policies are more expansive, the closer the next election. Economic policy is significantly less expansive when a flexible exchange rate regime has been adopted.

With respect to the influence of the Fund, the coefficient of new IMF loans is insignificant in all regressions. There is thus no support for the hypothesis that the Fund's loans lead to worse economic policy by increasing governments’ budgetary leeway. Neither do the results support the hypothesis that IMF lending induces moral hazard with the borrowers. Quota exhaustion never has a significant effect on monetary growth. Depending on the proxy for compliance included, budget deficits even rise with quota exhaustion (column 2a and 2b of Table 2). This might reflect the consequences of debt service resulting from previous IMF programs. As the results show, programs with greater compliance do not have a stronger impact on policies than non-implemented programs do. This result is in line with Killick, Malik and Manuel (1992), finding no evidence of a significant connection between program implementation and the achievement of desired results.

With respect to IMF programs, the results are more positive for the Fund. Standby and EFF arrangements significantly reduce monetary expansion in the regressions covering the 
period from the 1970s-90s, while they have no effect in the shorter period from 1992-2000. The same is true for the budget deficit which is also significantly reduced by loans and programs under all IMF facilities in column 1a and 1c. The results show that the IMF's concessional programs increase the budget deficit over the period 1992-2000. This probably indicates that the poor countries borrowing under the Poverty Reduction and Growth Facility could not borrow from other sources which did not allow them to run the deficits they prefer.

According to the estimates, an IMF program reduces the budget deficit between 5 and 9 percentage points, while monetary growth is reduced by about 500-600 percentage points. The huge impact on money expansion is driven by some outlying countries experiencing hyperinflation. If they are excluded, the coefficients become much smaller. They remain significant.

In summary, there is some evidence that participation in IMF Standby and EFF programs improves economic policy. Money disbursed and the exhaustion of a country's quota with the Fund do not have a systematic influence. The degree to which programs are completed also has no impact on fiscal and monetary policies.

The final section discusses policy implications arising from this.

\section{POLICY IMPLICATIONS AND CONCLUSION}

The International Monetary Fund has come under increased scrutiny and attack, with some of the most intense criticisms aiming at the ineffectiveness of its programs and conditionality. Combining findings of the recent literature with the results of this study, IMF loans, conditions and programs seem to be ineffective in achieving structural change that would lead to greater economic freedom and growth (e.g. Boockmann and Dreher 2003, Dreher 2004a). They do also seem to induce moral hazard with the borrowing countries: although budget deficits and monetary expansion are lower during program periods, policies do not improve in the long-run, but deteriorate instead (e.g. Evrensel 2002). The Fund has 
been shown to be an almost continuous provider of aid to a few dozens of developing countries and emerging market economies. Failure to comply with spirit and conditions of its programs are not effectively punished by the Fund. At worst, programs are cancelled. After that, negotiations for a new program can start immediately, and new money is agreed upon, and disbursed. The circle starts again.

There are obvious policy implications. Economic policies could be improved on a more permanent basis, first, by establishing conditionality on an ex-ante basis (as suggested by Vaubel 1991, the International Financial Institutions Advisory Commission (IFIAC) 2000, Dreher and Vaubel 2004a). For example, all member states in which monetary expansion exceeds an n-year moving average of real GDP growth by more than x percent ought to be excluded from credits. With respect to fiscal policy, a limit for the budget deficit relative to GDP could be set (as is now in force in the European Union). ${ }^{5}$ Additional ex ante conditions could refer to a sound and solvent banking and financial system, the freedom of entry and operations of foreign financial institutions, the timely release of accurate information on the country’s financial position, and the avoidance of pegged exchange rates (Meltzer 2005).

The current practice of IMF conditionality is clearly inadequate. To facilitate public scrutiny, the conditions ought to be few and simple, and they ought to be published without exception (Vaubel 1991). The Fund should also be obliged to inform the public whether the conditions have been implemented and, if not, why additional installments of the credit have been paid out.

The second point is related. The IMF seems to lend to incompetent governments more frequently than to competent ones (Dreher 2004c). Although many arrangements break down, the Fund immediately starts to negotiate a new program after the break-down. Past compliance does not seem to be important for future credits (Bird 2002, Dreher 2003). The only pre-requisite for Fund money seems to be (alleged) acceptance of certain conditions. It has been argued by Dollar and Svensson (2000), however, that imposing conditionality on 
reluctant governments is doomed to failure. Instead of trying to impose such conditionality, development agencies should only support countries with "good” policies. Most importantly, they have to identify and support reform-minded governments. Ideally, development institutions would support those governments with grants instead of loans. But should the IMF really be a development institution? This leads to the next criticism.

Since IMF loans do, third, not lead to changes in structural, growth-oriented policies, recent criticism is endorsed, demanding the Fund to scale back its mandate in order to restrain its activities to key areas of expertise, providing short term balance of payments credits, and to let the World Bank deal with development goals (e.g. IFIAC 2000). This could be achieved by raising the opportunity costs of borrowing from the Fund. The interest rate subsidy could be eliminated (Vaubel 1991). The interest rate on the loan could even be made contingent on compliance (Dreher 2003). Low compliance would lead to an interest penalty. If the interest rate subsidy would generally be replaced by a penalty as recommended by the IFIAC (2000), the IMF would become a lender of last resort. In the past, it has rather been a lender of first resort.

The Fund's Contingent Credit Line established in 1999 and expired in 2003 implemented part of these suggestions. Specifically, it provided for ex ante conditionality. But it had been designed in such a way that it could not function and, indeed, it has never been used. To be eligible, the potential borrowers had to sign up in advance, thereby signaling that they anticipate a crisis and a need for credit. To be effective, ex ante conditionality has to be mandatory and universal. But then it would be very difficult for the IMF's major shareholders to abuse Fund lending for political reasons.

Given the rather obvious flaws in the design of the IMF's lending procedure, why is a reform of the Fund so difficult? First, as outlined in detail in Dreher (2004b) those reforms are simply not in the interest of those who have to implement them - the staff of the IMF. Second, those reforms are not in the interest of the Fund's major shareholders either. It is 
these shareholders who are in charge of the major issues in the Fund (Fratianni and Pattison 2003). A reform of IMF lending and conditionality therefore has to aim at decision makers in G7 countries. But even if politicians in those countries could be convinced that reforms are beneficial, incentives to actually push for reforms are low. According to Olson's theory of collective action (1965), with a huge number of shareholders, the share in the benefits from reforming an organization is small. As a consequence, the governments of the member states have no interest in monitoring the performance of the Fund, especially when the costs of persuading the other member governments that reform is necessary are substantial. ${ }^{6}$

In summary, prospects for a sensible reform are bleak. 


\footnotetext{
* Thurgau Institute of Economics, Switzerland and University of Konstanz, Department of Economics, Box D 131, 78457 Konstanz, Germany, E-mail: mail@axel-dreher.de
}

Acknowledgements: I thank participants of the conference 'Debt Relief and Global Governance', Rotterdam, June 17-18, 2004 for helpful comments and Martin Edwards as well as Rouben Atoian, Alexandros Mourmouras and Saleh Nsouli for sharing their data on program interruptions.

${ }^{1}$ A detailed summary of the consequences of IMF programs is Haque and Khan (1998). For an in-depth analysis of fiscal adjustment under IMF programs see IEO (2003).

${ }^{2}$ One would also like to control for the stringency of conditionality. Dreher (2004b) and Dreher and Vaubel (2004b) used the number of conditions included in the IMF program as proxy. However, those data are not available for a sufficient number of years and countries, and can therefore not be used here.

${ }^{3}$ Vreeland (2003) provides an extensive discussion of the selection problem in the context of IMF programs. For a detailed representation of the underlying formula, see Goldstein and Montiel (1986).

${ }^{4}$ Note that real GDP growth and the dummy for flexible exchange rates are included in the policy regressions also, reducing the number of instruments for IMF loans. Similarly, the rate of monetary expansion is included in the IMF program equation; it is endogenous to the system.

${ }^{5}$ As is currently discussed with respect to the EU, this limit could depend on economic cycles instead of being a fixed number.

${ }^{6}$ Vaubel, Dreher and Soylu (2005) provide empirical support for this hypothesis employing a sample of 27 international organizations over the years 1950-2001. 


\section{References}

Beck, T.; Clarke, G.; Groff, A.; Keefer, P. and P. Walsh (2001), “New tools in comparative political economy: The Database of Political Institutions”, World Bank Economic Review 15, 1, 165-176.

Beveridge, W.A. and M.R. Kelly (1980), “Fiscal Content of Financial Programs Supported by Stand-By Arrangements in the Upper Credit Tranches, 1969-78”, IMF Staff Papers 27, 205-249.

Bird, G. (2002), “The Completion Rate of IMF Programmes: What We Know, Don’t Know and Need to Know”, The World Economy 25, 6, 833-847.

Bird, G. and T. Willett (2004), IMF Conditionality, Implementation and the New Political Economy of Ownership, mimeo.

Boockmann, B. and A. Dreher (2003), “The Contribution of the IMF and the World Bank to Economic Freedom”, European Journal of Political Economy 19, 3, 633-649.

Conway, P. (1994), “IMF lending programs: Participation and impact”, Journal of Development Economics 45, 365-391.

Dollar, D. and J. Svensson (2000), "What Explains the Success or Failure of Structural Adjustment Programs?”, Economic Journal 110, 894-917.

Dreher, A. (2003), “The Influence of Elections on IMF Program Interruptions”, The Journal of Development Studies 39, 6: 101-120.

Dreher, A. (2004a), IMF and Economic Growth: The Effects of Programs, Loans, and Compliance with Conditionality, mimeo, Exeter University.

Dreher, A. (2004b), “A Public Choice Perspective of IMF and World Bank Lending and Conditionality”, Public Choice 119, 3-4, 445-464.

Dreher, A. (2004c), “The Influence of IMF Programs on the Re-election of Debtor Governments”, Economics \& Politics 16, 1, 53-76. 
Dreher, A. and R. Vaubel (2004a), "Do IMF and IBRD cause moral hazard and political business cycles? Evidence from panel data”, Open Economies Review 15, 1, 5-22.

Dreher, A. and R. Vaubel (2004b), “The Causes and Consequences of IMF Conditionality”, Emerging Markets Finance and Trade 40, 3, 26-54.

Edwards, M.S., 2001, Crime and Punishment: Understanding IMF Sanctioning Practices, mimeo, Rutgers University.

Edwards, S. (1989), “The International Monetary Fund and the Developing Countries: A Critical Evaluation”, Carnegie-Rochester Conference Series on Public Policy: IMF Policy Advice, Market Volatility, Commodity Price Rules and other Essays, NorthHolland, 7-68.

Evrensel, A. (2002), "Effectiveness of IMF-Supported Stabilization Programs in Developing Countries”, Journal of International Money and Finance 21, 5, 565-587.

Fischer, S. (2001), “Address in Moscow”, IMF Survey 30, 14, July 16, 2001, 237-239.

Fratianni, M. and J. Pattison (2003), Who is running the IMF: Critical Shareholders or the Staff? mimeo.

Goldstein, M. and P. Montiel (1986), “Evaluating Fund Stabilization Programs with Multicountry Data”, IMF Staff Papers 33, 304-344.

Haggard, S. (1985), “The Politics of Adjustment: Lessons from the IMF’s Extended Fund Facility”, International Organization 39, 3, 505-534.

Haque, N.U. and M.S. Khan (1998), Do IMF-Supported Programs Work? A Survey of the Cross-Country Empirical Evidence, IMF Working Paper 98/169.

Independent Evaluation Office of the IMF (2003), Evaluation of Fiscal Adjustment in IMFSupported Programs, September 9, Washington, D.C.

International Financial Institution Advisory Commission (2000), Report, Washington, D.C., Government Printing Office. 
International Monetary Fund (2001), Structural Conditionality in Fund-Supported Programs, February 16, http://www.imf.org.

International Monetary Fund (2003), International Financial Indicators, CD-ROM, Washington, DC.

Killick, T. (1994), “Adjustment and Economic Growth”, in: J.M. Boughton and K.S. Lateef (eds.), Fifty Years after Bretton Woods - The Future of the IMF and the World Bank, International Monetary Fund and World Bank Group, Washington, D.C., 139-159.

Killick, T. (1995), IMF Programmes in Developing Countries - Design and Impact, Routledge, London.

Killick, T.; Malik, M. and M. Manuel (1992), "What Can We Know About the Effects of IMF Programmes”, The World Economy 15, 5: 575-597.

Marshall, M.G. and K. Jaggers (2000), Polity IV Project: Political Regime Characteristics and Transitions, 1800-2000, http://www.cidcm.umd.edu/inscr/ polity/.

Meltzer, A.H. (2005), Reviving the Bank and the Fund, Review of International Organizations, forthcoming.

Mercer-Blackman, V. and A. Unigovskaya (2004), “Compliance with IMF Program Indicators and Growth in Transition Economies”, Emerging Markets Finance and Trade 40, 3: 55-83.

Nsouli, S.; Mourmouras, A. and R. Atoian (2003), IMF Program Implementation, Institutional and Political Environment, and Macroeconomic Outcomes, mimeo.

Olson, M. (1965), The Logic of Collective Action, Cambridge, Mass.: Harvard University Press.

Przeworski, A. and J.R. Vreeland (2000), “The Effect of IMF Programs on Economic Growth”, Journal of Development Economics 62, 385-421. 
Vaubel, R. (1983), “The Moral Hazard of IMF Lending”, in: A.H. Meltzer (ed.), International Lending and the International Monetary Fund: A Conference in Memory of Wilson E. Schmidt, Heritage Foundation, Washington, D.C., 65-79.

Vaubel, R. (1991), “The Political Economy of the International Monetary Fund: A Public Choice Approach”, in: R. Vaubel and T.D. Willett (eds.), The Political Economy of International Organisations, Boulder, Westview, 205-245.

Vaubel, R.; Dreher, A. and U. Soylu (2005), “Staff Growth in International Organizations: A Principal-Agent Problem? An Empirical Analysis”, in: J.-r. Chen and D. Sapsford (eds.), Principles of International Institutions - Theoretical Foundations and Empirical Evidence, Edward Elgar Publishing, forthcoming.

Vreeland, J.R. (2003), The IMF and Economic Development. Cambridge: Cambridge University Press.

World Bank (2001), Global Development Finance, CD-ROM, Washington, DC.

World Bank (2003), World Development Indicators, CD-ROM, Washington, DC. 
Table 1: Determinants of IMF programs and loans (1975-2000)

\begin{tabular}{lccc}
\hline \multicolumn{1}{c}{ IMF Programs in effect } & \multicolumn{2}{c}{ New IMF Loans (in percent of GDP) $)^{\mathrm{a}}$} \\
\hline $\begin{array}{l}\text { Government consumption } \\
\text { (in percent of GDP) }\end{array}$ & 0.02 & Real GDP growth & -0.01 \\
Monetary expansion (percent) & $\left(4.70^{*}\right)$ & & $\left(2.83^{*}\right)$ \\
& -0.001 & Flexible exchange rate, & -0.17 \\
Government fractionalization & $\left(2.46^{* *}\right)$ & Dummy & $\left(3.21^{*}\right)$ \\
& -0.42 & Government special & -0.26 \\
& $\left(2.27^{* *}\right)$ & Interest, Dummy & $\left(3.71^{*}\right)$ \\
& & Lagged endogenous & 0.13 \\
& & variable & $\left(4.75^{*}\right)$ \\
\hline Number of Countries & & & \\
Number of observations & 96 & & 77 \\
Method of Estimation & 1814 & & OLS \\
$\mathrm{R}^{2}$ & Probit & & 0.04 \\
Joint significance (Prob>F) & & & 0.000 \\
\hline
\end{tabular}

Notes:

$\mathrm{t}$-statistics in parentheses.

Levels of significance: 1 percent $(*), 5$ percent $(* *)$.

${ }^{\mathrm{a}}$ The regression includes a different intercept for each country. 
Table 2: Effect of the IMF on Overall Budget Deficits (1975-2000, IMF loans and programs instrumented, 3SLS)

\begin{tabular}{lccccccccc}
\hline & \multicolumn{1}{c}{ All IMF loans/ programs } & \multicolumn{3}{c}{ Standby/ EFF } & \multicolumn{3}{c}{ SAF/ PRGF } \\
\hline & $(1 \mathrm{a})$ & $(1 \mathrm{~b})$ & $(1 \mathrm{c})$ & $(2 \mathrm{a})$ & $(2 \mathrm{~b})$ & $(2 \mathrm{c})$ & $(3 \mathrm{a})$ & $(3 \mathrm{~b})$ & $(3 \mathrm{c})$ \\
\hline New IMF loans & -0.61 & 1.27 & -0.55 & 2.87 & 2.00 & 2.05 & 0.87 & -5.63 & 0.60 \\
& $(0.47)$ & $(0.84)$ & $(0.37)$ & $(1.48)$ & $(1.22)$ & $(1.07)$ & $(0.20)$ & $(1.51)$ & $(0.13)$ \\
IMF program in effect & -5.30 & -0.61 & -5.28 & -9.32 & -2.46 & -7.60 & -4.17 & 10.52 & -3.64 \\
& $\left(2.95^{*}\right)$ & $(0.49)$ & $\left(2.95^{*}\right)$ & $\left(3.50^{*}\right)$ & $(1.61)$ & $\left(3.00^{*}\right)$ & $(0.89)$ & $\left(3.20^{*}\right)$ & $(0.76)$ \\
Quota exhaustion & 0.004 & 0.01 & 0.003 & 0.01 & 0.01 & 0.01 & 0.003 & 0.001 & 0.003 \\
(t-1) & $(1.20)$ & $(1.57)$ & $(0.69)$ & $\left(2.08^{* *}\right)$ & $\left(1.82^{\circ}\right)$ & $(1.47)$ & $(1.47)$ & $(0.52)$ & $(1.48)$ \\
IMF programs * & -0.15 & -2.52 & 1.48 & -3.13 & -1.84 & -0.75 & -0.09 & 0.35 & 0.60 \\
Compliance & $(0.08)$ & $(1.11)$ & $(1.02)$ & $(1.44)$ & $(0.87)$ & $(0.44)$ & $(0.40)$ & $(1.24)$ & $\left(3.11^{*}\right)$ \\
Real GDP growth & -0.09 & -0.18 & -0.09 & -0.06 & -0.14 & -0.07 & -0.06 & -0.23 & -0.08 \\
& $\left(2.66^{*}\right)$ & $\left(2.58^{* *}\right)\left(2.48^{* *}\right)$ & $(1.53)$ & $\left(1.72^{\circ}\right)$ & $\left(1.71^{\circ}\right)$ & $\left(2.17^{* *}\right)$ & $\left(5.31^{*}\right)$ & $\left(2.76^{*}\right)$ \\
Years left in current & -0.18 & -0.12 & -0.14 & -0.23 & -0.19 & -0.19 & -0.19 & -0.15 & -0.16 \\
Term & $\left(2.20^{* *}\right)$ & $(1.64)$ & $\left(1.72^{\circ}\right)$ & $\left(2.47^{* *}\right)$ & $\left(2.13^{* *}\right)$ & $\left(2.09^{* *}\right)$ & $\left(2.45^{* *}\right)$ & $\left(1.73^{\circ}\right)$ & $\left(2.04^{* *}\right)$ \\
Flexible exchange, & -0.84 & -1.03 & -0.86 & -0.39 & -0.90 & -0.56 & -1.04 & -0.84 & -1.04 \\
Rate, Dummy & $\left(1.83^{\circ}\right)$ & $\left(2.07^{* *}\right)$ & $\left(1.88^{\circ}\right)$ & $(0.73)$ & $\left(1.81^{\circ}\right)$ & $(1.06)$ & $\left(2.35^{* *}\right)$ & $(1.47)$ & $\left(2.39^{* *}\right)$ \\
Lagged endogenous & 0.41 & 0.22 & 0.42 & 0.37 & 0.18 & 0.39 & 0.42 & 0.36 & 0.43 \\
& $\left(10.11^{*}\right)$ & $\left(3.84^{*}\right)$ & $\left(11.06^{*}\right)$ & $\left(7.96^{*}\right)$ & $\left(2.93^{*}\right)$ & $\left(9.33^{*}\right)$ & $\left(11.06^{*}\right)$ & $\left(4.35^{*}\right)$ & $\left(11.17^{*}\right)$ \\
\hline Number of countries & 67 & 58 & 68 & 67 & 58 & 67 & 67 & 58 & 67 \\
Number of obs. & 892 & 387 & 913 & 892 & 387 & 913 & 892 & 387 & 913 \\
$\mathrm{R}^{2}$ & 0.57 & 0.67 & 0.57 & 0.38 & 0.58 & 0.46 & 0.68 & 0.10 & 0.68 \\
\hline
\end{tabular}

Notes:

Compliance is proxied by the share of agreed IMF loans actually disbursed (1a, 2a, 3a), Nsouli, Mourmouras and Atoian's measure for 'no major interruption during the program period' (1b, 2b, 3b) and, respectively, Edwards' variable for program continuation (1c, 2c, 3c).

t-statistics in parentheses.

Levels of significance: 1 percent $(*), 5$ percent $\left({ }^{* *}\right), 10$ percent $\left({ }^{0}\right)$.

All regressions include dummies for each year and country. 
Table 3: Effect of the IMF on Money Growth (1975-2000, IMF loans and programs instrumented, 3SLS)

\begin{tabular}{lccccccccc}
\hline & \multicolumn{1}{c}{ All IMF loans/ programs } & \multicolumn{3}{c}{ Standby/ EFF } & \multicolumn{3}{c}{ SAF/ PRGF } \\
\hline & $(1 \mathrm{a})$ & $(1 \mathrm{~b})$ & $(1 \mathrm{c})$ & $(2 \mathrm{a})$ & $(2 \mathrm{~b})$ & $(2 \mathrm{c})$ & $(3 \mathrm{a})$ & $(3 \mathrm{~b})$ & $(3 \mathrm{c})$ \\
\hline New IMF loans & 5.28 & 78.32 & 23.66 & 121.48 & 116.43 & 157.86 & 484.49 & 142.88 & -443.09 \\
& $(0.04)$ & $(0.41)$ & $(0.15)$ & $(0.55)$ & $(0.73)$ & $(0.70)$ & $(0.72)$ & $(0.61)$ & $(0.67)$ \\
IMF program in effect & -244.00 & -86.41 & -296.28 & -509.68 & -125.05 & -622.31 & 12.50 & -225.53 & -36.83 \\
& $(1.34)$ & $(0.83)$ & $(1.61)$ & $\left(1.91^{\circ}\right)$ & $(1.00)$ & $\left(2.28^{* *}\right)$ & $(0.02)$ & $(1.02)$ & $(0.05)$ \\
Quota exhaustion & 0.15 & 0.09 & 0.14 & 0.50 & 0.04 & 0.56 & 0.25 & 0.13 & 0.25 \\
(t-1) & $(0.49)$ & $(0.21)$ & $(0.44)$ & $(0.83)$ & $(0.09)$ & $(0.95)$ & $(1.20)$ & $(1.04)$ & $(1.23)$ \\
IMF programs * & -35.41 & 78.18 & -12.45 & -110.50 & 88.53 & -114.01 & 26.11 & 2.39 & 12.21 \\
Compliance & $(0.19)$ & $(0.28)$ & $(0.09)$ & $(0.49)$ & $(0.43)$ & $(0.61)$ & $(0.87)$ & $(0.16)$ & $(0.76)$ \\
Real GDP growth & -5.12 & -0.77 & -4.66 & -4.63 & -2.84 & -4.34 & -6.11 & 2.14 & -5.36 \\
& $\left(1.69^{\circ}\right)$ & $(0.11)$ & $(1.45)$ & $(1.25)$ & $(0.42)$ & $(1.15)$ & $\left(1.86^{\circ}\right)$ & $(0.89)$ & $\left(1.85^{\circ}\right)$ \\
Years left in current & -17.61 & -1.40 & -16.27 & -18.52 & 0.68 & -17.90 & -15.45 & -0.33 & -15.04 \\
Term & $\left(2.40^{* *}\right)$ & $(0.25)$ & $\left(2.12^{* *}\right)$ & $\left(2.20^{* *}\right)$ & $(0.09)$ & $\left(2.05^{* *}\right)$ & $\left(2.10^{* *}\right)$ & $(0.08)$ & $\left(2.10^{* *}\right)$ \\
Flexible exchange, & -106.71 & -110.38 & -104.51 & -82.88 & -113.51 & -74.55 & -116.83 & -108.36 & -117.17 \\
Rate, Dummy & $\left(2.41^{* *}\right)$ & $\left(2.62^{*}\right)$ & $\left(2.41^{* *}\right)$ & $(1.52)$ & $\left(3.02^{*}\right)$ & $(1.38)$ & $\left(2.70^{*}\right)$ & $\left(3.88^{*}\right)$ & $\left(2.75^{*}\right)$ \\
Lagged endogenous & 0.22 & 0.41 & 0.22 & 0.22 & 0.41 & 0.22 & 0.23 & 0.39 & 0.23 \\
& $\left(8.71^{*}\right)$ & $\left(8.28^{*}\right)$ & $\left(8.91^{*}\right)$ & $\left(8.06^{*}\right)$ & $\left(7.76^{*}\right)$ & $\left(7.84^{*}\right)$ & $\left(8.68^{*}\right)$ & $\left(8.45^{*}\right)$ & $\left(8.87^{*}\right)$ \\
\hline Number of countries & 68 & 59 & 68 & 68 & 59 & 68 & 68 & 59 & 68 \\
Number of obs. & 922 & 402 & 944 & 922 & 402 & 944 & 922 & 402 & 944 \\
R & 0.27 & 0.43 & 0.24 & 0.10 & 0.34 & 0.03 & 0.22 & 0.44 & 0.22 \\
\hline
\end{tabular}

Notes:

Compliance is proxied by the share of agreed IMF loans actually disbursed (1a, 2a, 3a), Nsouli, Mourmouras and Atoian's measure for 'no major interruption during the program period' (1b, 2b, 3b) and, respectively, Edwards' variable for program continuation (1c, 2c, 3c).

t-statistics in parentheses.

Levels of significance: 1 percent $\left({ }^{*}\right), 5$ percent $(* *), 10$ percent $\left({ }^{\circ}\right)$.

All regressions include a different intercept for each country. 